\title{
Öğretmen Yetiştirme ve Öğretmen Niteliğine İlişkin Resmi Belgelerde Eleștirel Düşünme ve Öğretiminin Yeri
}

\author{
Serap YILMAZ ÖZELÇİ ${ }^{1}$ (iD)
}

${ }^{1}$ Necmettin Erbakan Üniversitesi, Konya, Türkiye

\begin{tabular}{|c|c|}
\hline Makal & ÖZ \\
\hline $\begin{array}{l}\text { Makale Geçmişi } \\
\text { Geliş: 04.10.2020 } \\
\text { Kabul: 16.11.2020 } \\
\text { Yayın: } 29.12 .2020 \\
\text { Anahtar Kelimeler: } \\
\text { Öğretmen Yetiştirme } \\
\text { Öğretmen Niteliği } \\
\text { Eleştirel Düşünme } \\
\text { Eleştirel Düşünmenin } \\
\text { Öğretimi }\end{array}$ & 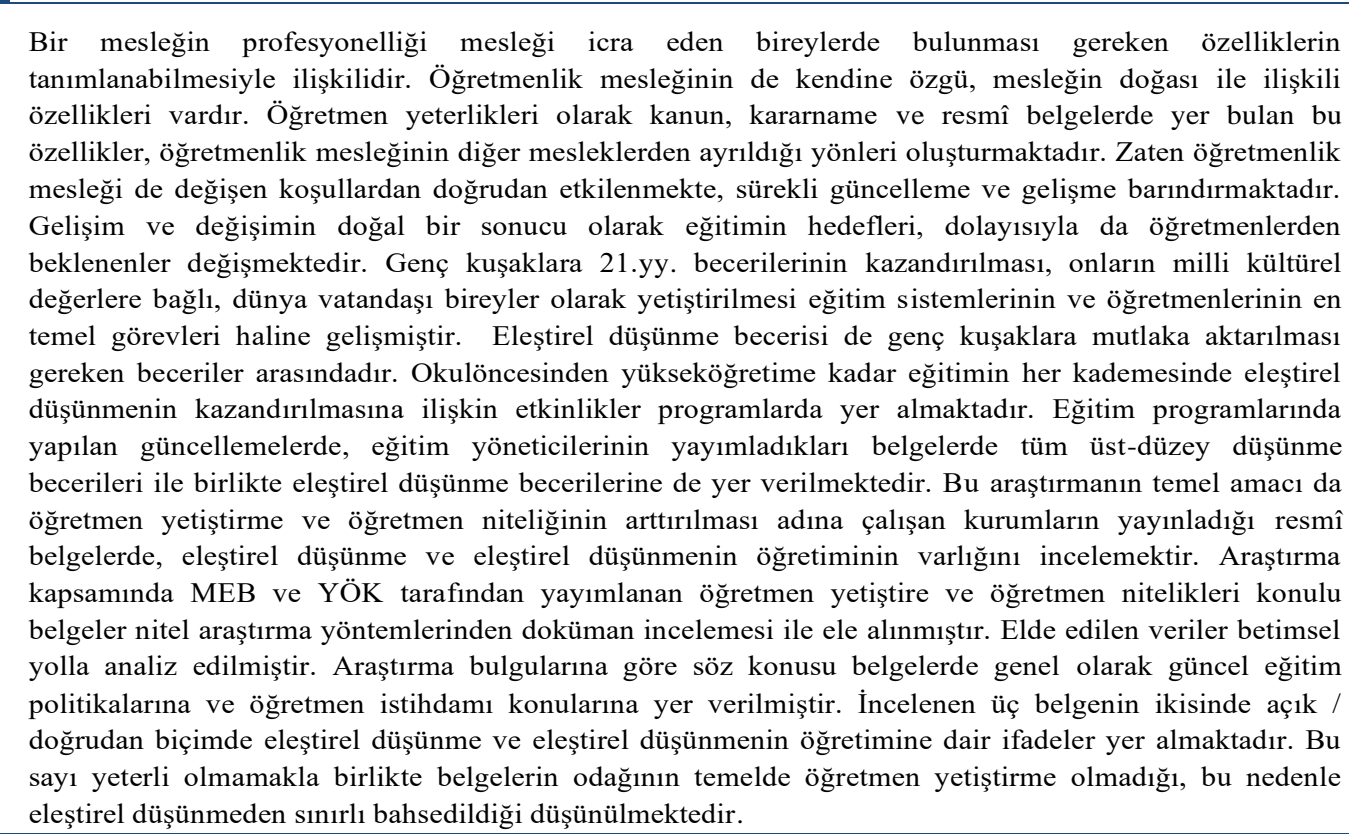 \\
\hline
\end{tabular}

\section{The Place of Critical Thinking and Teaching in Official Documents Regarding Teacher Training and Teacher Qualificaitions}

\begin{tabular}{l}
\hline Article Info \\
\hline Article History \\
Received: 04.10.202 \\
Accepted: 16.11 .202 \\
Published: 29.12 .2 \\
Keywords: \\
Teacher Training \\
Teacher \\
Qualification \\
Critical Thinking \\
Teaching Critical \\
Thinking
\end{tabular}

\section{ABSTRACT}

The professionalism of a profession, related to defining the characteristics that should be found in individuals who perform the profession. The teaching profession has its own characteristics related to the nature of the profession. These features, which are included in laws, decrees and official documents as teacher competencies, constitute the aspects that distinguish the teaching profession from other professions. Anyway, the teaching profession is directly affected by the changing conditions, and it contains continuous updating and development. As a natural result of development the goals of education systems, and accordingly, the expectations from teachers change. Critical thinking is one of skills that must be transferred to young generations by teachers. Activities related to gaining critical thinking at all levels of education are included in the programs. Critical thinking skills are included in the updates made in the education programs and in the documents published by the education administrators. The main purpose of this study is to examine the existence of teaching critical thinking and critical thinking in the official documents published by institutions working to teacher traing and increase teacher qualifications. The obtained data were analyzed in a descriptive way. According to the findings, current education policies and teacher employment issues are generally included in these documents. In two of the three documents examined, there are statements on teaching critical thinking in an explicit / direct form. Although this number isn't sufficient, it's thought that the focus of the documents is not mainly teacher training, so critical thinking is limited. 


\section{GíRiş}

Ülkeler eğitim sistemleri aracıllğıyla nitelikli insan gücü yetiştirme ve toplumsal gelişimi sağlamayı hedeflemektedir. $\mathrm{Bu}$ hedefler doğrultusunda eğitim programları geliştirilir. Öğretmenler de geliştirilen bu programları sınıflarda uygulayarak ülkenin hedeflerini hayata geçirmek için yoğun çaba gösterir. Bu bağlamda, hedefe giden yolda en temel öğelerden birisinin öğretmenler olduğu söylenebilir. Tarihi uzun yıllar öncesine dayanan, ilk dönemlerinde meslek olarak tanımlayan öğretmenlik; günümüzde profesyonel bir meslektir (Aydın, 2018; Boncuk, 2020; Dönmez ve Özkul, 2020; Ersoy, 2018; Güven, 2010). Türkiye'de öğretmenliğin meslek olarak kabulü iki aşamalı olmuştur. Mart 1924'te "devletin umumi hizmetlerinden talim ve terbiye vazifesini üzerine alan, müstakil sinıf ve derecelere ayrlan bir meslektir” şeklinde tanımlanan öğretmenlik, daha sonra Haziran 1973'te (1739 sayılı Milli Eğitim Temel Eğitim Kanunu) uzmanlık gerektiren bir meslek olarak ele alınmış ve "devletin eğitim, öğretim ve bununla ilgili yönetim görevlerini üzerine alan özel bir ihtisas mesleği” olarak yeniden tanımlanmıştır (Akyüz, 2008). Profesyonel meslek tanımında o meslekle uğraşanlarda bulunması gereken özellikleri de yer almaktadır. Öğretmen olabilmek için, belirli bir süreyi kapsayan yoğun içerikli bir (alan bilgisi, meslek bilgisi, genel kültür) eğitim gerekmektedir. Ayrıca daha iyi öğretmen olabilmek için de daha fazla bilgi, beceri ve tutuma (Pieper, 1999, akt: Dönmez ve Özkul, 2020; Milli Eğitim Bakanlığı [MEB], 2017) sahip olmak gerekmektedir. Öğretmen yeterlikleri olarak tanımlanan bu bilgi, beceri ve tutumlar; kanun, kararname ve resmi belgelerde yer almaktadır. Bu yeterlikler hem öğretmenlik mesleğini diğer mesleklerden ayırmakta hem de mesleğin sürekli güncellenmesi ve gelişmesini gerekli kılmaktadır (Özdemir, 2016). Öğretmen, baskın politik felsefenin genç nesillere aktarılmasında rol oynar. Toplumsal norm ve değerlerin, bu toplumu oluşturacak yeni bireylere öğretilmesinde önemli bir yerdedir (Karataş, 2020). Bu anlamda eğitim felsefesinin ve toplumun öğretmene yüklediği anlam, görev ve sorumluluk son derece büyüktür. Öğretmenlik mesleği; öğretmenlerin neleri bilmesi ve neleri yapabilmesi gerektiğine ilişkin beklentinin sürekli değiştiği dinamik özelliği olan bir meslektir. Eğitim yöneticileri de bu dinamizmin 1şığında zaman zaman öğretmenlik mesleğinin görev ve sorumluluklarına ilişkin güncellemeler, yeni tanımlamalar yapmaktadır.

Günümüzde toplumlar karmaşık, öngörülemeyen ve buna bağlı olarak planlanamayan bir dönüşüm süreci geçirmektedir (örn. 2019 sonlarında başlayan ve etkisini sürdüren pandemi tüm dünyada eğitim, sağlık ve ekonomi alanlarını doğrudan etkilemiş, köklü değişikliklere sebep olmuştur). Bu dönüşüm insanların nasıl çalıştığını, nasıl iletişim kurduklarını, sosyal ilişkilerini nasıl yürüttüklerini, nasıl yaşadıklarını ve en önemlisi nasıl öğrendiklerini de değiştirmektedir (TED, 2009). Bireylerin öğrenme tercihleri değişmekte; buna bağlı olarak öğretmenlerin sahip olması gereken öğretim becerileri de değişmektedir. Son dönemde dünya genelinde hakim olan bakış açısı yeni nesle 21.yy becerilerinin kazandırılması, milli ve kültürel değerlere bağlı, dünya vatandaşı bireylerin yetiştirilmesidir (Anagün, Alatay, Kılıç ve Yaşar, 2016; MEB, 2017, MEB, 2018, Tekerek, Karakaya, Tekerek, 2018). Eleştirel düşünme becerisi de bu temel beceriler arasında yer almaktadır. Okulöncesinden yükseköğretime eğitimin her kademesinde vurgulanması amaçlanan temel beceriler arasındadır. Çünkü küresel ölçekte yaşanan değişimlere ayak uydurabilmenin en temel yollu üst düzey düşünme becerilerine ve eleştirel düşünme becerisine sahip olmaktır (Fisher, 2001). Ennis (1985) eleştirel düşünmeyi bir şeyi yapmadan ya da bir şeye inanmadan önce nedenleri doğru değerlendirme, sorgulama, yoğun düşünme ve sonrasında karar verme olarak tanımlamaktadır. Bu bağlamda özellikle henüz hizmet öncesi dönemde olan ve eksikliklerinin tamamlanması ve geliştirilmesi aşamasında olan öğretmen adaylarının eleştirel düşünme becerisi kazanarak mezun olmaları önemlidir. Çünkü ancak bu biçimde öğrencilerine bu konuda rol model olabileceklerdir.

2005 yılından bu yana ilk olarak ilköğretim programlarında daha sonra da diğer tüm eğitim kademelerinin öğretim programlarında yaşanan paradigma dönüşümü, öğretmen ve öğretmen adaylarının da değişip dönüşmesini zorunlu kılmıştır. Önce öğrenmeye bakış açısında başlayan, daha sonra da eğitim sistemlerini etkileyen bu dönüşüm yeni nesil öğrenenlerin karşına çıkacak öğretmen modelini de değiştirmiştir. Düşüncelerini açık ve anlaşılır biçimde ifade edebilen, tartışmaya ve fikir paylaşımına açık, karşısındakini etkin dinleyebilen, üst düzey düşünme becerilerine sahip öğretmenlere ihtiyaç duyulmaktadır. Eleştirel düşünen, yaşadıkları olayların sorumluluğunu alabilen bireylerden oluşan bir toplum için öğretmenlerin sınıf içinde sergiledikleri tutum ve davranışlar son derece önemlidir. Çünkü öğretmenlerin öğretim sürecinde verdiği mesajlar, yaşama ilişkin algıları, bilime yönelik tutumları ve düşünme biçimleri, sınıf içindeki davranışlarına etki edebilmektedir (Yılmaz-Özelçi, 2012). Öte yandan eleştirel düşünen, soran, sorgulayan bireyler yetiştirmek için öncelikle öğretmenlerin bu becerilere sahip olması gerekmektedir (Kazancı, 1989; Seferoğlu ve Akbıyık, 2006). Bu nedenle eğitim yöneticileri sıklıkla yayınladıkları belgelerde tüm üst düzey düşünme becerileriyle birlikte eleştirel düşünmeye de yer vermektedirler. Bilimsel komisyonlar tarafından hazırlanan bu belgelerin içeriğinin hayata geçirilebilmesi ise, politik bakış açısından uzak, eleştirel gözle irdelenmesi ile mümkün 
olacaktır. Bu bağlamda öncelikle metinlerde nelerin vurgulandığının bilimsel düzlemde tartışılması önemlidir. Tüm bu gerekçelerle araştırmanın amacı öğretmen yetiştirme ve öğretmen niteliğini geliştirme adına hizmet eden iki temel kurum olan Yükseköğretim Kurumu (hizmet öncesi) ve Milli Eğitim Bakanlığı (hizmet içi) tarafından yayınlanan belgeleri eleştirel düşünme ve eleştirel düşünmenin öğretimi bağlamında incelemektir. Bu temel amaç doğrultusunda şu sorulara yanıt aranmıştır:

1. Öğretmen Yetiştirme Lisans Programlarında eleştirel düşünmenin yeri nedir?

2. Öğretmen Yetiştirme Lisans Programlarında eleştirel düşünme öğretiminin yeri nedir?

3. Öğretmen Strateji Belgesi 2017-2023'te eleştirel düşünmenin yeri nedir?

4. Öğretmen Strateji Belgesi 2017-2023’te eleştirel düşünme öğretiminin yeri nedir?

5. Öğretmenlik Mesleği Genel Yeterlikleri Belgesi'nde eleştirel düşünmenin ve yeri nedir?

6. Öğretmenlik Mesleği Genel Yeterlikleri Belgesi’nde eleştirel düşünme öğretiminin yeri nedir?

\section{YÖNTEM}

\section{Araştırma Modeli}

Araştırmanın temel amacı öğretmen niteliğinin arttırılması adına çalışan kurumların yayınladığı resmi belgelerde, eleştirel düşünme ve eleştirel düşünmenin öğretiminin varlığını incelemektir. Araştırma kapsamında MEB ve YÖK tarafından yayımlanan öğretmen yetiştire ve öğretmen nitelikleri konulu belgeler nitel araştırma yöntemlerinden doküman incelemesi ile ele alınmıştır. Doküman incelemesi, araştırılması hedeflenen olgu veya olgular hakkında bilgi içeren yazılı materyallerin analizini kapsar (Büyüköztürk ve dig., 2016; Yıldırım ve Şimşek, 2005). Burada veri kaynağı geçmişteki bir resim, plak, ses kayıtları, kitap, ansiklopedi, tutanak vb. dokümanlar olabilir. Bu veriler diğer araştırma yöntemleri içinde kullanılabileceği gibi başlı başına bir araştırmanın veri setini de oluşturabilirler (Yıldırım ve Şimşek, 2005)

\section{Veri Toplama Araçları ve Süreçleri}

Araştırmanın veri toplama aracını YÖK tarafından Mayıs, 20018'de yayınlanan Öğretmen Yetiştirme Lisans Programları, 2017 yılında MEB tarafından yayınlanan Öğretmen Strateji Belgesi 2017-2023 ve yine 2017 yılında MEB tarafından güncellenen Öğretmenlik Mesleği Genel Yeterlilikleri Belgesi metni oluşturmaktadır. Tüm bu metinler araştırma amacı (eleştirel düşünme ve eleştirel düşünmenin öğretimine yapılan vurgu) kapsamında incelenmiş ve analiz edilmiştir. Veri kaynakları 2017-2018 yıllarında söz konusu kurumlar tarafından yeni yayınlanan ya da güncellenen 3 belge ile sınırlıdır.

\section{Verilerin Analizi}

Araştırma kapsamında elde edilen verilerin analizinde betimsel analiz yönteminden yararlanılmıştır. Betimsel analizde elde edilen veriler, daha önceden belirlenen temalara göre yorumlanır. Veriler önce mantıklı ve anlaşılır bir şekilde betimlenir, sonra bu betimlemeler yorumlanır, neden-sonuç ilişkileri irdelenir ve birtakım sonuçlara ulaşılır. Amaç bulguların okuyucuya belirli bir çerçevede düzenlenmiş ve yorumlanmış biçimde sunmaktır (Yıldırım ve Şimşek, 2005). Eldeki araştırmada da veri kaynağı olarak kullanılan metinlerde aranacak tema / temalar araştırma amacı doğrultusunda önceden belirlenmiştir. Eleştirel düşünme ve eleştirel düşünmenin öğretimi, temaları doğrultusunda metinler taranmıştır.

\section{Araştırmanın Geçerlik ve Güvenilirliği}

Nitel çalışmalarda iç geçerlik, araştırma bulgularının ve yapılan yorumların doğruluğu yansıtıp yansıtmadığını, katılımcı ve araştırmacının süreçteki bakış açısının nasıl olduğunun ortaya konmasıdır. Bulgu ve yorumlar araştırmacının kişisel beklentilerinden arınık olarak sunulmalıdır (Creswell, 2016; Frankel ve Wallen, 2003; Yıldırım ve Şimşek, 2005).

Araştırmada veri analizi için öncelikle metinler araştırmacı tarafından farklı zamanlarda tekrar tekrar okunup kodlanmış, daha sonra bu kodlar karşılaştırılarak tutarlılık sağlanmaya çalışılmıştır. Ortaya çıkan 
kodlamaların uygunluğu Eğitim Programları ve Öğretim Anabilim dalından iki uzmanın görüşüne sunulmuştur. Verilerde sayısallaştırma yapılmadığından uyuşum katsayısı hesaplanmamıştır.

\section{Etik}

Araştırmada etik kurul onayı gerektiren türde veri kullanılmamıştır.

\section{BULGULAR}

Araştırmada elde edilen bulgular ele alınan metindeki eleştirel düşünme ve eleştirel düşünmenin öğretimi başlıkları birleştirilerek sunulmuştur.

\section{Öğretmen Yetiştirme Lisans Programlarında Eleştirel Düşünme ve Eleştirel Düşünmenin Öğretimi}

Araştırma kapsamında 2018 yılında güncellenen 25 öğretmen yetiştirme lisans programı incelenmiştir. YÖK tarafından yayımlanan metin güncellemenin gerekçesi, yapı ve getirilen yenilikler ve 25 öğretmen yetiştirme lisans programına ait ders içerikleri bölümlerinden oluşmaktadır. Genel olarak bakıldığında metnin paydaşları bilgilendirme amacı taşıdığı söylenebilir. Öğretmen niteliklerine açık bir dille vurgu yapılmamakla birlikte daha önceden yayımlanmış ulusal ve uluslararası metinler referans gösterilmiştir. Değişen öğretmen nitelikleri ve mevcut programlarda görülen eksiklikler açıklanmaya çalışılmıştır. Ancak metinde doğrudan eleştirel düşünme ve eleştirel düşünmenin öğretiminden söz edilmemektedir. Güncellemenin gerekçesi başlığı altında öğretmen yeterliliklerinden kapalı bir ifade içinde söz edilmekle birlikte araştırma kapsamında ele alınan diğer belgelere atıfta bunulmuştur. Metinde geçen ifade aşağıda verilmiştir:

“...Bu bă̆lamda Öğretmenlik Mesleği Genel Yeterlikleri yeniden hazırlanarak 2017 yılında yayımlanmıştır. Ayrıca 2017 yılında Öğretmen Strateji Belgesi yayımlanmıştır. Söz konusu belgelerde, öğretmenlikle ilgili yeni yeterlikler yanında yeni hedeflere ve beklentilere yer verilmiştir."

Yine "Güncellemenin Gerekçesi” başlı̆̆ı altında öğretmen adayının taşıması gereken kimi özelliklere değinilmiştir. İçerik bağlamında ele alındığında bu özelliklerin eleştirel düşünen birey özellikleri ile ilişkilendirilebilir. Söz konusu açıklama şöyledir:

“...yeni lisans programlarında öğretmen adaylarının, alanıyla ilgili mesleki bilgi ve beceriler yönünden yeterli bir donanıma sahip olmalar yanında sosyal, kültürel, moral, entelektüel yönlerden donanımlı ve gelişmiş bir kişiliğe sahip olarak yetiştirilmesi, daha insani ve erdemli bir ülkenin ve dünyanın inşasında aktif rol alacak ahlaki ve kültürel liderler olarak yetiştirilmesi beklenmektedir. Bu nedenle programlardan mezun olacak ögretmen dayının; (i) evrensel, milli ve yerel/bölgesel kültürleri ve bunlar arasındaki ortak ve farkl yanları tanıması; (ii) kültürel, etik, ahlaki değerler ve kişilik yönünden rol model olması, (iii) teknoloji okuryazarı, araştırmacı ögretmen niteliği kazanmış olarak mezun olması beklenmektedir."

Öğretmen Yetiştirme Lisans Programları, lisans bazında tek tek ele alındığında eleştirel düşünme ve öğretimine ilişkin en dikkat çekici vurgu tüm programlarda kendine yer bulan "Eleştirel ve Analitik Düşünme" dersinde görülmektedir. Meslek Bilgisi Seçmeli Dersleri arasında yer alan dersin içeriği programda şöyle açıklanmıştır:

"Temel kavramlar ve tanımlar; düşünme organı olarak beyin, düşünme biçimleri ve düşünmenin gruplandırlmasl; istemsiz düşünme ve özellikleri; istemli düşünme ve özellikleri; istemli düşünmenin yöntemleri; eleştirel ve analitik düşünme; eleştirel ve analitik düşünmenin temel özellikleri ve kriterleri, eleştirel ve analitik düşünmenin aşamalart; eleştirel ve analitik düşünmeyi etkileyen faktörler; eleştirel ve analitik düşünmenin kapsami; eleştirel ve analitik okuma; eleştirel ve analitik dinleme; eleştirel ve analitik yazma."

Tüm programlar incelendiğinde, eleştirel düşünmeye vurgu yapan dersler genel olarak dil öğretimi (Arapça, İngilizce, Japonca ve Türkçe öğretmenliği) görülmektedir. Alan Eğitimi ve Alan Eğitimi Seçmeli Dersiler 
arasında yer alan derslere ve ders içeriğindeki ifadelere ilişkin detaylı bilgi tablo 1'de yer almaktadır. Tablo 1 incelendiğinde yalnızca 2 programda (Felsefe Grubu Öğretmenliği / Düşünme Eğitimi ve Türkçe Öğretmenliği / Eleştirel Okuma) doğrudan ders adı ve içerik tanımlaması olarak eleştirel düşünmeye yer verildiği görülmektedir. Diğer programlarda ise ders içeriklerinin içinde kazanım olarak ifade edilmiştir.

Tablo 1.

Eleştirel Düşünme ve Öğretimine İlişkin Ífadeler, Derslerin Adı ve Bulunduğu Programlar

\begin{tabular}{llll}
\hline Program Ad1 & Türü & Dersin Adı & İçerikte Yer Alan İfade \\
\hline $\begin{array}{l}\text { Almanca } \\
\text { Öğretmenliği }\end{array}$ & Alan Eğitimi & Okuma Becerileri 1 & $\begin{array}{l}\ldots \text { analizi ve değerlendirilmesi } \\
\text { temeline dayanan eleştirel düşünme } \\
\text { becerilerinin geliştirilmesi. }\end{array}$ \\
\hline & & & $\begin{array}{l}\ldots \text { bilginin sentezlenmesi, analizi ve } \\
\text { değerlendirilmesi temeline dayanan } \\
\text { eleştirel düşünme becerilerinin } \\
\text { geliştirilmesi. }\end{array}$
\end{tabular}

Öğretmenliği

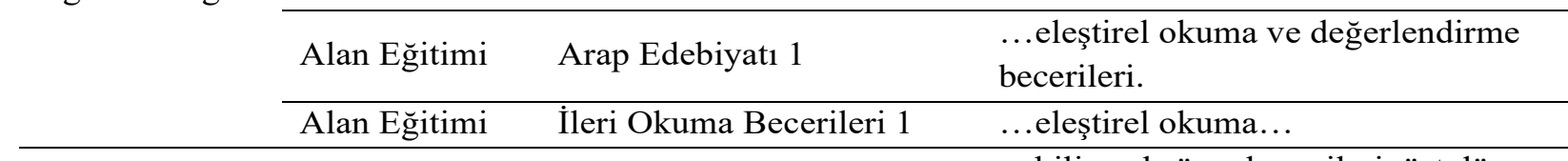

\begin{tabular}{ll}
\hline Biyoloji & Alan Eğitimi $\quad$ Biyoloji Öğretimi 1 \\
Ögetmenliği &
\end{tabular}

...bilimsel süreç becerileri, üst düzey

Ogretmenliği $\quad$ sorgulayıcı) ve yaşam becerileri,

Düşünmenin mahiyeti; düşünme üzerine çeşitli düşünürlerin görüşleri;

Felsefe Grubu Öğretmenliği

Alan Eğitimi Düşünme Eğitimi çeşitli düşünme biçimleri; düşünme

Ŏ̆

eğitimi programları, çocuklar için

felsefe programları ile çeşitli uygulamaların gerçekleştirilmesi; eleştirel ve analitik düşünme.

\begin{tabular}{|c|c|c|c|}
\hline & & & \\
\hline $\begin{array}{l}\text { Fransizca } \\
\text { Öğretmenliği }\end{array}$ & Alan Eğitimi & Okuma Becerileri I & $\begin{array}{l}\text {...bilginin sentezlenmesi, analizi ve } \\
\text { değerlendirilmesi temeline dayanan } \\
\text { eleştirel düşünme becerilerinin } \\
\text { geliştirilmesi. }\end{array}$ \\
\hline \multirow[t]{2}{*}{$\begin{array}{l}\text { İngilizce } \\
\text { Öğretmenliği }\end{array}$} & Alan Eğitimi & Okuma Becerileri I & $\begin{array}{l}\text {...bilginin sentezlenmesi, analizi ve } \\
\text { değerlendirilmesi temeline dayanan } \\
\text { eleştirel düşünme becerilerinin } \\
\text { geliştirilmesi. }\end{array}$ \\
\hline & Alan Eğitimi & Eleştirel Okuma ve Yazma & $\begin{array}{l}\text { İçerikte eleştirel düşünmeye ilişkin } \\
\text { özel bir vurgu yer almamaktadır. }\end{array}$ \\
\hline \multirow{2}{*}{$\begin{array}{l}\text { Japonca } \\
\text { Öğretmenliği }\end{array}$} & Alan Eğitimi & Okuma Becerileri I & $\begin{array}{l}\text {...bilginin sentezlenmesi, analizi ve } \\
\text { değerlendirilmesi temeline dayanan } \\
\text { eleştirel düşünme becerilerinin } \\
\text { geliştirilmesi. }\end{array}$ \\
\hline & Alan Eğitimi & İleri Okuma Becerileri II & $\begin{array}{l}\text { Bilginin birleştirilmesi, problemin } \\
\text { çözümlenmesi ve değerlendirme } \\
\text { sonucu tepki verme gibi ileri düzey } \\
\text { eleştirel düşünme becerileri }\end{array}$ \\
\hline $\begin{array}{l}\text { Özel Eğitim } \\
\text { Öğretmenliği }\end{array}$ & Alan Eğitimi & $\begin{array}{l}\text { Özel Eğitimde Türkçe } \\
\text { Öğretimi }\end{array}$ & $\begin{array}{l}\text {..eleştirel okuma; yaratıcı yazma; } \\
\text { okuma metni analiz yöntemleri; }\end{array}$ \\
\hline $\begin{array}{l}\text { Resim-İş } \\
\text { Öğretmenliği }\end{array}$ & $\begin{array}{l}\text { Alan Eğitimi } \\
\text { Seçmeli } \\
\text { Dersler }\end{array}$ & Sanat Eleştirisi & $\begin{array}{l}\text {...sanat eserlerini inceleyerek eleştirel } \\
\text { düşünmeyi geliştirme... }\end{array}$ \\
\hline
\end{tabular}




\begin{tabular}{|c|c|c|c|}
\hline $\begin{array}{l}\text { Sinıf } \\
\text { Öğretmenliği }\end{array}$ & Alan Eğitimi & Türkçe Öğretimi & $\begin{array}{l}\text {...okuma ve yazma yoluyla eleştirel } \\
\text { düşüncenin geliştirilmesi... }\end{array}$ \\
\hline $\begin{array}{l}\text { Sosyal Bilgiler } \\
\text { Öğretmenliği }\end{array}$ & Alan Eğitimi & $\begin{array}{l}\text { Medya Okuryazarlığı ve } \\
\text { Eğitimi }\end{array}$ & $\begin{array}{l}\text {...medyaya yönelik eleştirel bakış } \\
\text { açısı..., ... medyayı eleştirel okuma... }\end{array}$ \\
\hline \multirow[t]{2}{*}{$\begin{array}{l}\text { Türkçe } \\
\text { Öğretmenliği }\end{array}$} & $\begin{array}{l}\text { Alan Eğitimi } \\
\text { Seçmeli } \\
\text { Dersler }\end{array}$ & Eleştirel Okuma & $\begin{array}{l}\text { Eleştirel düşünme tanımı ve kapsamı, } \\
\text { eleştirel düşünme stratejileri; okuma } \\
\text { ve anlama; okuma yaklaşımları; metin } \\
\text { türlerini ve retorik özelliklerini tanıma, } \\
\text { akıl yürütme stratejilerini belirleme, } \\
\text { uygulama çalışmaları. }\end{array}$ \\
\hline & $\begin{array}{l}\text { Alan Eğitimi } \\
\text { Seçmeli } \\
\text { Dersler }\end{array}$ & Medya Okuryazarlığı & $\begin{array}{l}\text {...eleştirel okuma, eleştirel dinleme ve } \\
\text { izleme; }\end{array}$ \\
\hline
\end{tabular}

\section{Öğretmenlik Mesleği Genel Yeterlikleri Belgesi’nde Eleştirel Düşünme ve Eleştirel Düşünmenin Öğretimi}

2006 yılından bu yana güncellenerek yayınlanmaya devam eden öğretmen yeterlikleri belgesinde öğretmen yeterlikleri; "öğretmenlik mesleğini etkili ve verimli biçimde yerine getirebilmek için sahip olunması gereken bilgi, beceri ve tutumlar" olarak tanımlanmaktadır. Mesleki Bilgi (Alan bilgisi, alan eğitimi bilgisi ve mevzuat bilgisi), Mesleki Beceri (eğitim-öğretimi planlama, öğrenme ortamları oluşturma, öğretme ve öğrenme sürecini yönetme, ölçme ve değerlendirme) ve Tutum ve Değerler (Milli manevi ve evrensel değerler, öğrenciye yaklaşım, iletişim ve işbirliği, kişisel ve mesleki gelişim) başlıklarında sunulan bu yeterliklere ait göstergeler de metinde belirtilmiştir.

Araştırma kapsamında ele alınan eleştirel düşünme ve eleştirel düşünmenin öğretimine dair açık ya da örtük bir mesaja rastlanmamıştır. Yalnızca Mesleki Bilgi yeterlik alanı altında yer alan Alan Bilgisi alt alan yeterliğinin tanımlamasında eleştirel düşünme becerisi ile ilişkilendirilebilecek ifadelere rastlanmaktadır. Yine Mesleki Beceri yeterli alanı altında yer alan Ortamı Oluşturma alt alan yeterliğine ve Öğretme ve Öğrenme Sürecini Yönetme alt alan yeterliğine ilişkin göstergelerde eleştirel düşünme becerisine ait ifadelere rastlanmaktadır. Söz konusu alanlar ve göstergeler tablo 2'de verilmiştir.

Tablo 2.

Öğretmenlik Mesleği Genel Yeterliklerinde Eleştirel Düşünme ve Öğretimine İlişkin Ífadeler

\begin{tabular}{|c|c|c|}
\hline Yeterlik Alanı & Yeterlikler & Yeterlik Göstergesi \\
\hline Mesleki Bilgi & A1. Alan Bilgisi & $\begin{array}{l}\text { A1. Alanında sorgulayıcı bakış açısını kapsayacak şekilde } \\
\text { ileri düzeyde kuramsal, metodolojik ve olgusal bilgiye } \\
\text { sahiptir (ifade gösterge olarak değil yeterliğin açıklaması } \\
\text { olarak verilmiştir). }\end{array}$ \\
\hline Mesleki Beceri & $\begin{array}{l}\text { B2. Öğrenme Ortamı } \\
\text { Oluşturma } \\
\text { B3. Öğretme ve Öğrenme } \\
\text { Sürecini Yönetme }\end{array}$ & $\begin{array}{l}\text { B2.6. Öğrencilerin üst düzey bilişsel becerilerini geliştirici } \\
\text { öğrenme ortamları oluşturur } \\
\text { B3.7. Öğrencilerin derslerde analitik düşünmelerine yönelik } \\
\text { etkinlikler hazırlar }\end{array}$ \\
\hline
\end{tabular}

\section{Öğretmen Strateji Belgesi 2017-2023’te Eleştirel Düşünme ve Eleştirel Düşünmenin Öğretimi}

Öğretmen yetiştirme ve niteliğinin geliştirilmesinde "yol haritası” olmayı amaçlayan 2017-2023 Strateji Belgesi'nde 3 temel amaç ve bu amaçlara ilişkin hedefler belirlenmiştir. 1. Amaç Yüksek Nitelikli, İyi Yetişmiş ve Mesleğe Uygun Bireylerin Öğretmen Olarak İstihdamını Sağlamak, 2. Amaç Öğretmenlerin Kişisel ve Mesleki Gelişimini Sürekli Kılmak ve 3. Amaç Öğretmenlik Mesleğine Yönelik Algıyı İyileştirmek ve Mesleğin Statüsünü Güçlendirmek olarak tanımlanmış ve hedeflere ilişkin açıklamalarda bulunulmuştur. Öğretmen niteliği bağlamında daha çok hizmet öncesi uygulamanın arttırılmasına dikkat 
çekilmiş ve eğitimin tamamlayan adaylar arasında en nitelikli olanlarının belirlenmesine yönelik bir sistemin kurulmasına değinilmiştir. Ancak, 32 sayfalık metinde eleştirel düşünme ve eleştirel düşünmenin öğretimine ilişkin açık ya da örtük bir mesaja rastlanmamıştır. Yalnızca metnin "sunuş" ve "giriş" kısımlarındaki genel ifadeler arasında eleştirel düşünmeye yer verilmiştir.

"Ĕ̆itim sistemlerinin nihai amacl; topluma faydal,, toplumsal değerleri gözeten, etkili iletişim becerilerini edinmiş, değişime uyum să̆layabilen, öğrenme kaynaklarına erişme ve bunlardan etkin bir şekilde yararlanma becerilerini kazanmış, bilgi iletişim teknolojilerini verimli kullanabilen, kendisiyle ve toplumla barışık, inisiyatif alan, araştıran, sorgulayan ve eleştirel düşünme becerilerine sahip özgür bireyler yetiştirebilmektir...” (Sunuş bölümünde)

“Günümüz dünyasında öğrenmeyi ögrrenme, problem çözme, takım üyesi olma ve eleştirel düşünme ile bilgi ve iletişim teknolojilerini kullanma yetkinliği ögrencilere kazandırllmasi gereken temel beceriler olarak ön plana çıkmıştır..." (Giriş bölümünde)

\section{TARTIŞMA / SONUÇ / ÖNERI}

\section{Tartışma ve Yorum}

Öğretmen yetiştiren ve öğretmen istihdam eden kurumların öğretmen niteliklerini geliştirme amacıyla yayınladıkları resmi belgelerin eleştirel düşünme ve eleştirel düşünmenin öğretimi bağlamında incelendiği bu araştırmada MEB (2) ve YÖK tarafından 2017-2018 yıllarında yayımlanan toplam 3 belge ele alınmıştır. Öğretmen yetiştirme lisans programları (YÖK, 2018), öğretmenlik mesleği genel yeterlikleri (MEB, 2018) ve öğretmen strateji belgesi 2017-2023 (MEB, 2017) belgelerinin içeriği eleştirel düşünme ve eleştirel düşünmenin öğretimine ilişkin ifade ve açıklama içerip içermemesi bakımından incelenmiştir. Araştırma bulgularına göre söz konusu belgelerde genel olarak eğitim politikalarına yer verilmiştir. Öğretmen niteliğine ilişkin tanımlamalarda eleştirel düşünme tanımına doğrudan yer verilmemiştir. Her üç metinde de eleştirel düşünen birey özellikleri vurgulanmıştır. Metinlerde öğretmen yeterlikleri ve nitelikleri konularında temel vurgu nitelikli öğretmen istihdamıdır. Öğretmen adayları arasından en niteliklerinin belirlenmesi ya da mevcut öğretmenlerde en iyi performansın değerlendirmesiyle eğitimde kalitenin yakalanabileceği öne sürülmektedir (MEB, 2018). Elbette ki bu belgelerin öğretmenlik mesleğinin statüsü, özlük hakları ve diğer beklentileri noktasında da bilgi ve açıklama içermesi gerekmektedir. Ancak çok özellik bakımından çok boyutluluğa sahip, duyuşsal yönleri yoğunlukta olan öğretmenlik mesleğinde ihtiyaçların bunlardan (en iyiyi seçme, en iyiyi ödüllendirme) ibaret olmadığı bilinmektedir. Ayrıca bu belgeler değişen ve dönüşen eğitim paradigması karşısında kendini yetersiz ya da geri kalmış hissetmemesi için öğretmenlere ve öğretmen adaylarına yol gösterici nitelikte olmalıdır. Öğretmen, öğretmen adayı, eğitim yöneticisi, akademisyen gibi eğitimin tüm paydaşlarının ilgi ve merakla takip ettiği bu bilgilendirme belgelerinde öğretmenin niteliğine ilişkin daha somut beyanlara gereksinim duyulduğu düşünülmektedir.

Araştırma bulgularına göre iki farklı belgede açık ifadelerle eleştirel düşünmeye yer verilmiştir. Bunlardan birisi eleştirel düşünmeye diğeri ise eleştirel düşünmenin öğretimine değinmektedir. Öğretmen yetiştirme lisans programlarında yer alan, Meslek bilgisi seçmeli derslerinden "Eleştirel ve Analitik Düşünme" dersi içeriği bakımından ele alındığında, dersin öğretmen adaylarında eleştirel düşünme becerisini ve farkındalığını geliştirmeyi amaçladığı görülmektedir. Dersin kazanımlarının amacına ulaşması hem öğretmen adayının kişisel gelişimi adına hem de öğretmenlik mesleğinin niteliğinin artırılması adına önemlidir. Yine Öğretmen yetiştirme lisans programlarında düşünme eğitimi, eleştirel okuma gibi dersler alan eğitim dersleri arasında görülmektedir. Eleştirel düşünme, temel üst düzey düşünme becerileri arasında yer almaktadır. İlköğretim programlarında “eleştirel düşünme; kuşku temelli sorgulayıcı bir yaklaşımla konulara bakma, yorum yapma ve karar verme becerisi olarak tanımlanmaktadır. Ayrıca sebep-sonuç ilişkilerini bulma, ayrıntılarda benzerlik ve farklılıkları yakalama, çeşitli ölçütleri kullanarak sıralama yapma, verilen bilgilerin kabul edilebilirliğini geçerliliğini belirleme, analiz etme, değerlendirme, anlamlandırma, çıkarımda bulunma gibi alt becerileri içermektedir (MEB, 2004, 734)" biçiminde 
tanımlanan eleştirel düşünme öğretmen yetiştirme programlarında bağımsız bir ders olarak yerini 2018 yılında alabilmiştir. İlköğretim programlarında öğrenciye kazandırılması gereken temel becerilerden biri olarak tanımlanan eleştirel düşünme; öğrencilere içerik aracılığıyla aktarılabilir. Ancak bu becerinin kazandırılmasında daha etkili olacağı düşünülen diğer yol ise öğretmen davranışıdır. Çünkü öğretmenlerin düşünme ve yorumlama gerektiren aktivitelerde öğrenciye rol model olması, öğrencilerinin düşüncelerini geliştirici tutum ve davranış sergilemeleri en az içerik kadar etkilidir. Bu bağlamda eğitim fakültelerinin öğretmenleri akademik donanıma eriştirmenin yanında; onların bilime bakış açılarını, düşünme kapasitelerini ve bu kapasitelerini kullanabilme yeterliklerini de geliştirmeyi amaçlamaları gerekmektedir. Çünkü eleştirel düşünme öğrenilen bir beceridir ve eleştirel düşünme eğitiminin bireylerde bu becerinin gelişmesine katkı sağladığı bilinmektedir (Kökdemir, 2003). Lisans düzeyinde öğretmenlere sunulacak eleştirel düşünme eğitiminin, eleştirel düşünür öğretmen yetiştirmesi; eleştirel düşünür öğretmenin de eleştirel düşünür öğrenci yetiştirmesi söz konusudur. Değişen eğitim paradigmasında da öğretmenin temel özellikleri olaylar karşısında önyargısız olma, kendi yeterliklerinin bilincinde olma, nesnel ve bilişsel değerlendirme yapabilme olarak tanımlanmaktadır (Atalay, 2005; Tezer, 1998). Söz konusu özellikler aynı zamanda eleştirel düşünen birey özellikleridir. Bu niteliklere sahip öğretmenler onları kendilerine rol model alan öğrenciler için oldukça önemlidir. Çünkü öğrencilerinde düşünmeye ilişkin olumlu tutum ve beceri geliştirebilmek, olaylara bakış açılarını bilimsellik ölçütüne dayandırabilmek, bilimsel tutum geliştirebilmek adına çabalaması beklenen öğretmenlerin söz konusu özelliklere yeterli düzeyde sahip olmadıkları görülmektedir (Kazanc1, 1989; OECD, 1994). Bu nedenle "Eleştirel ve Analitik Düşünme" dersinin öğretmen niteliğine katkı sağlayacağı düşünülmektedir.

Eldeki araştırma bulgularına göre eleştirel düşünmenin öğretimine ilişkin ifadeler daha çok Öğretmenlik Mesleği Genel Yeterliklerinde yer almaktadır. Öğretmen yeterliklerinin ve yeterlik göstergelerinin maddeler halinde sunulduğu belgede, "Öğrencilerin üst düzey bilişsel becerilerini geliştirici öğrenme ortamları oluşturur" ve "Öğrencilerin derslerde analitik düşünmelerine yönelik etkinlikler hazırlar" göstergeleri eleştirel düşünmenin öğretimi ile doğrudan ilişkilidir. Eleştirel düşünmenin öğretiminde üç temel yaklaşım bulunmaktadır. Beceri temelli yaklaşım, içerik temelli yaklaşım ve bütüncül yaklaşım (Aybek, 2007; Kurnaz, 2007; Vural ve Kutlu, 2005). Söz konusu göstergelerden ilkinin beceri temelli yaklaşımı, ikincisinin ise içerik temelli yaklaşımı barındırdığı söylenebilir. Eleştirel düşünmeyi destekleyen bir öğrenme ortamını oluşturan unsurlar; sınıf düzeni, öğrenci davranışları, öğretmeninin davranışları, öğrenme etkinlikleri ve eğitim materyalleridir (Beyer, 1991; akt. Polat, 2014). Tok'a (2008) göre, eleştirel düşünme öğretiminde ilk basamak eleştirel düşünmeyi geliştirici öğrenme ortamların oluşturmasıdır. Bu ortamlarda öğretmenler, öğrencilerin derse aktif katılımlarını desteklemelidir. Önemli olan öğretmenlerin bu ortamı oluştururken öncelikle kendilerinin çok iyi bir model olmalarının gerekliliğidir. Ancak unutulmamalıdır ki öğretmenlerin öğretimsel becerileri de bu süreçte etkilidir. Eleştirel düşünmenin öğretimini amaçlayan öğretmen; sınıf içinde açık, etkileşimli ve demokratik bir atmosfer oluşturup, hoşgörülü davranmalıdır. Ders kitaplarının ve ders programlarının ötesinde, öğrenci ilgi ve ihtiyaçları doğrultusunda içerik belirleyebilmeli, etkinliklerini anlamsal bütünlük içinde sunabilmelidir. Öğrenciyi bir birey olarak kabul ettiğini ve onun düşüncelerine saygı duyduğunu hissettirmelidir (Gürkaynak, Üstel ve Gülgöz, 2003). Tüm bunları da eğitim aldığı süreç boyunca eğitim fakültesinde önce kendisi tecrübe etmelidir.

Türkiye'de öğretmen yetiştirme programlarının ortak hedeflerine bakıldığında "edindiği temel düzeydeki bilgi ve becerileri eleştirel bir yaklaşımla değerlendirir" ve "eleştirilere açıktır, eleştirilerini kırmadan yapar" ifadeleri sıklıkla tekrarlanmaktadır (MEB, 2018; Türk Eğitim Derneği [TED], 2009; YÖK, 2011). Eleştirel düşünme hem beceri hem de davranış olarak vurgulanmıştır. Öğretmen adayları okulda kaldıkları süre içerisinde bu hedeflere yönelik öğretimsel etkinliklere katılmaktadırlar. Bu da yukarıda da vurgulandığı gibi, öğrencilerine öğretebilmek için eleştirel düşünme becerisine önce kendilerinin sahip olması gerektiğine ilişkin farkındalık olarak değerlendirilmektedir. 


\section{Sonuç ve Öneriler}

Araştırma bulguları, öğretmen yetiştirme ve öğretmen niteliklerini konu alan resmi belgelerde öğretimsel içerikten daha çok eğitim politikaları ve istihdama ilişkin açıklamalara yer verildiğini göstermiştir. Metinlerin sunuş bölümlerinde artık dillere pelesenk olan ifadelerle yetiştirilmek insan modeli tanımlansa da, ilerleyen bölümlerde genel olarak eğitim politikalarından söz edilmekte, hizmet içi eğitimler ve performansa dayalı ödüllendirme sisteminin öğretmen niteliğini arttırmaya katkı sağlayabileceği öne sürülmektedir. Araştırma kapsamında incelenen üç belgenin ikisinde açık / doğrudan eleştirel düşünme ve eleştirel düşünmenin öğretimine dair ifade yer almaktadır. Bu sayı yeterli görülmemektedir. Belgelerin odağının ise eğitimde politikalarının paydaşlarla paylaşılması olduğu, bu nedenle de öğretmen niteliklerine ilişkin detaylı açıklamalara gidilmediği düşünülmektedir. Elde edilen bulgular 1şığında şu önerilerde bulunulmuştur:

- Öğretmen yetiştirmede hizmet öncesi ve hizmet içi gelişim adına çaba gösteren kurumlar, yayınladıkları belge içeriklerinde eğitim sisteminin tüm paydaşlarını düşünerek politik dilden uzak, açık ve detaylı anlatımlar kullanabilir.

- Öğretmen niteliklerinden söz edilirken öğretmen olan bireyde bulunması gereken temel kişilik özelliklerine de yer verilebilir. Burada olayları üst düşünme becerileri ve bilimsel tutum içinde değerlendirme bir kişilik özelliği olarak tanımlanabilir.

- Eleştirel düşünme becerisinin bireylere kazandırılmasının önemi düşünüldüğünde öğretmen yetiştirme programlarında meslek bilgisi seçmeli dersleri arasında yer alan Eleştirel ve Analitik Düşünme dersi "zorunlu" statüye getirilebilir.

\section{KAYNAKÇA}

Akyüz, Y. (2008). Türk eğitim tarihi (M.Ö. 1000-M.S. 2008) [Turkish education history (1000 BC-2008 $A D)$ ]. Ankara: Pegem Academic Publishing.

Anagün, S. Ş., Atalay, N., Kılıç, Z. \&Yaşar, S. (2016). Öğretmen adaylarına yönelik 21. yüzyıl becerileri yeterlilik algıları ölçeğinin geliştirilmesi: Geçerlik ve güvenirlik çalışması [The development of a 21st century skills and competences scale directed at teaching candidates: Validity and reliability study], Pamukkale University Journal of Education, 40 (2) 55-63.

Atalay, C. (2005). Öğretmen liselerindeki öğrencilerin kişilik özellikleri ve öğretmenlik mesleğine yönelik tutumlar arasindaki ilişkiler[Relationships between personality traits and attitudes towards the teaching profession of students in teacher high schools], (Unpublished master thesis), Selçuk University Scocial Sciences Institue: Konya.

Aybek, B. (2007). Konu ve beceri temelli eleştirel düşünme öğretiminin öğretmen adaylarının eleştirel düşünme eğilimi ve düzeyine etkisi [The effect of subject and skill-based critical thinking instruction on pre-service teachers' critical thinking disposition and level], (Unpublished Doctoral Disseration), Çukurova University Scocial Sciences Institue: Adana.

Aydın, İ. (2018). Öğretmenlik Kariyer Evreleri ve Öğretmenlerin Mesleki Gelişimi [Teaching Career Stages and Professional Development of Teachers], Journal of Human Sciences, 15(4), 2047-2065. doi: $10.14687 /$ jhs.v15i4.5450

Boncuk, A. (2020). 2023 Eğitim Vizyonu Belgesi’nde öğretmenlik mesleğine ilişkin politikaların öğretmen görüşlerine göre değerlendirilmesi [Evaluation of policies related to teaching profession in 2023 educational vision document according to teachers' opinions], Anatolian Turk Education Journal2020, 2(1), 55-73

Büyüköztürk, Ş. , Çakmak, E. K., Akgün, E. Ö., Karadeniz, Ş. \& Demirel, F. (2016). Bilimsel araştırma yöntemleri [Scientific research methods]. Ankara: Pegem Academy Publishing.

Creswell, J. W. (1998). Qualitative inquiry and research design: Choosing among five traditions. Thousand Oaks, CA: Sage. 
Dönmez, B., Özkul, R. (2020). Öğretmen andının öğretmenlik mesleki değerlerinin kazandırılmasına katkısı [Contribution of teacher's oath to gaining teaching professional values], Journal of National Education,49 (227), 345-370.

Ennis, R. (1985), Goals for Critical Thinking Curriculum, Wadsworth Publishing Company, Belmont (ERIC no:16476)

Ersoy, F. (2018).Öğretmenlik ve ahlak [teaching and etichs], In Erdoğmuş, N., Torlak, Ö., Tiryaki, B. K. (Ed.) Temelleri ve uygulamalariyla iş ahlakı [Business ethics with its fundamentals and practices] $\mathrm{p}$ (378-400), İstanbul: Turkey Venture Economics and Business Ethics Association Publications.

Fisher, A. (2001). Critical thinking: An introduction, Cambridge Universty Press

Fraenkel, J. R. and Wallen, N. E. (2006). How to design and evaluate research in education (6th ed.). New York: McGraw-Hill.

Gürkaynak, İ., Üstel, F., Gülgöz, S. (2003). Eleştirel düşünme [Critical thinking]. İstanbul: Istanbul Policy Center Education Reform Initiative Publication.

Güven, D. (2010). Profesyonel bir meslek olarak Türkiye'de öğretmenlik [As a professional teaching profession in Turkey]. Boğaziçi University Journal of Education, 27(2), 13-21.

Karataş, K. (2020). Öğretmenlik mesleğine kuramsal bir bakış [A theoretical view of the teaching profession], Electronic Journal of Education Science, 9 (17), 39-56. Retrieved form www.ejedus.org

Kazanc1 O. (1989), Eğitimde eleştirici düşünme ve öğretimi [Critical thinking and teaching in education], İstanbul: Kazanc1 Book I.C.

Kökdemir, D. (2003), Belirsizlik durumlarında karar verme ve problem çözme [Decision making and problem solving in situations of uncertainty], (Unpublished Doctoral Disseration), Ankara University: Ankara.

Kurnaz, A. (2007). Illköğretim beşinci sınıf sosyal bilgiler dersinde beceri ve içerik temelli eleştirel düşünme öğretiminin öğrencilerin eleştirel düşünme becerileri, erişi ve tutumlarına etkisi [The effect of skill and content-based critical thinking instruction on students' critical thinking skills, achievement and attitudes in the fifth grade social studies course], (Unpublished Doctoral Disseration), Selçuk University Scocial Sciences Institue: Konya.

Milli Eğitim Bakanlığı, (2004), Tebliğler Dergisi [Journal of Announcements], 67(2563), 734.

Milli Eğitim Bakanlığı, (2017), Öğretmen strateji belgesi 2017-2023. Retrieved from http://oygm.meb.gov.tr/meb_iys_dosyalar/2017_07/26174415_Strateji_Belgesi_RG-Ylan_26.07.2017.pdf.

Milli Eğitim Bakanlığı, (2018), Öğretmenlik mesleği genel yeterlikleri, retrieved from http://oygm.meb.gov.tr/meb_iys_dosyalar/2017_12/11115355_YYRETMENLYK_MESLEYY_GEN EL_YETERLYKLERY.pdf.

Organisation for Economic Co-operation and Development OECD (1994). Economic Studies No. 22, Spring 1994, URL: retrived from http://www.oecd.org/document/52/0,3343,en_2649_34117_33840116_1_1_1_1,00.html

Özdemir, M. S. (2016). Öğretmen niteliğinin bir göstergesi olarak sürekli mesleki gelişim [Continuous professional development as an indicator of teacher quality], Gazi Journal of Education Sciences, 2 (3), 233-244

Polat, S. (2014). Eleştirel düşünme becerisi ögrretiminin çok yönlü incelenmesi [Multi-faceted examination of critical thinking skills teaching], (Unpublished Doctoral Disseration), Necmettin Erbakan University Educational Sciences Institue: Konya.

Resmi Gazete (1973) Milli Eğitim Temel Kanunu [National Education Basic Law], Yasa No: 1739. (24.6.1973 date \& 14574 no)

Seferoğlu, S., Akbıyık, C. (2006). Eleştirel düşünme ve öğretimi, [Critical thinking and teaching], Hacettepe University Journal of Education, 30 (1), 193-200.

Tekerek, B., Karakaya, F. \& Tekerek, M. (2018). Öğretmen yetiştirme lisans programlarının 21. Yüzyıl becerileri açısından incelenmesi: ilköğretim matematik ve fen bilgisi örneği [An investigation on undergraduate programs of teacher training regarding 21th century skills: Example of elementary mathematics and science], Ankara University, journal Faculty of Educational Sciences, 27 (1), 71-85.

Tezer, F. (1998). İdeal öğretmenin kişilik özellikleri: Marmara Üniversitesi Atatürk Eğitim Fakültesi 
ögretmen adaylarının ideal öğretmenin kişilik özelliklerini algılamaları üzerine bir çalışma [Personality traits of the ideal teacher: A study on the perception of the personality traits of the ideal teacher by Marmara University Atatürk Education Faculty pre-service teachers], (Unpublished master thesis) Marmara University Scocial Sciences Institue: İstanbul.

Tok, E. (2008). Düşünme becerileri ĕgitimi programının okul öncesi öğretmen adaylarının eleştirel, yaratıcı düşünme ve problem çözme becerilerine etkisinin incelenmesi [Examining the effect of thinking skills training program on pre-school teacher candidates' critical, creative thinking and problem solving skills], (Unpublished Doctoral Disseration), Marmara University Educational Sciences Institue: İstanbul.

Türk Eğitim Derneği, (2009). Türk Eğitim Derneği öğretmen yeterlikleri [Turkish Education Association teacher qualifications] Ankara: Adım Okan Publication.

Vural, R. A. ve Kutlu, O. (2004). Eleştirel düşünme: Ölçme araçlarının incelenmesi ve bir güvenirlik çalışması [Critical thinking: Examination of measurement tools and a reliability study], Journal of Çukurova University Social Sciences Institute, 13 (12), 189-200.

Yıldırım, A. \& Şimşek, H. (2008). Sosyal bilimlerde araştırma yöntemleri [Research methods in social sciences], Ankara: Seçkin Publishing.

Yılmaz Özelçi, S. (2012). Eleştirel düşünme tutumuna etki eden faktörler: Sınıf öğretmeni adayları üzerine bir çalışma [Factors affecting critical thinking attitude: A study on classroom teacher candidates], (Unpublished Doctoral Disseration), Adnan Menderes University Social Sciences Institue:, Aydın.

Yükseköğretim Kurumu, (2011). Türkiye yükseköğretim yeterlilikler çerçevesi temel alan yeterlilikleri / ögretmen yetiştirme ve eğitim bilimleri, temel alan kodu: 14, Retrieved from http://tyyc.yok.gov.tr.

\section{EXTENDED ABSTRACT}

Introduction: Teaching, which dates back many years and defined it as a profession at first, is a professional profession today. The definition of a professional profession brings along the features that should be found in those who are engaged in that profession. These characteristics, which are included in laws, decrees and official documents as teacher competencies, constitute the aspects that distinguish the teaching profession from other professions, and require continuous updating and development as it is directly affected by changing conditions. The perspective that has dominated the world in recent years is the acquisition of 21 st century skills to the new generation and the training of world citizens who are bound by national cultural values. Critical thinking skill is also among these basic skills, and is seen as one of the basic skills that should be emphasized at all levels of education from preschool to higher education. Decision makers of educational policies often felt the need to include critical thinking along with all high-level thinking skills in the documents they published.

Materials and Methods: The aim of the study is to examine the documents published by the Higher Education Institution (pre-service) and the Ministry of National Education (in-service), which are the two main institutions serving in the name of teacher training and teacher qualification, in the context of teaching critical thinking and critical thinking. The research is designed as document analysis, one of the qualitative research methods. The data collection tool of the research consists of Teacher Training Undergraduate Programs published by YÖK in May, 20018, Teacher Strategy Document 2017-2023 issued by MEB in 2017 and Teacher Competencies Document text updated by MEB in 2017. All these texts have been examined and analyzed within the scope of the research objective (emphasis on teaching critical thinking and critical thinking). Descriptive analysis method was used to analyze the data.

Findings: Within the scope of the research, 25 teacher training language programs updated in 2018 were examined. The text, which includes the rationale of the update, the structure and innovations, and the content of the 25 teacher training undergraduate programs, does not directly mention the teaching of critical thinking and critical thinking. Under the title of the rationale for the update, teacher competencies are mentioned in a closed statement, and other documents discussed within the scope of the research are referred. Again, under the same heading, some features that prospective teachers should have are mentioned. Although it is thought that these features can be combined with the characteristics of the critical thinking individual when considered in the context of the content, there are no statements directly related to the teaching of critical thinking and critical thinking in the text. When the Teacher Training Undergraduate Programs are considered one by one, it is seen 
that critical thinking, critical reading or writing are included in some field education course contents. These expressions, which are included in language teaching-oriented programs (German, Arabic, Turkish teaching, etc.), appear in reading / advanced reading skills, literature classes, which are among the elective courses of field education. The clearest move regarding the teaching of critical thinking and critical thinking is seen as the inclusion of the "Critical and Analytical Thinking" course among the vocational knowledge electives.

Teacher competencies in the document of teacher competencies, which has been updated and published since 2006; It is defined as "the knowledge, skills and attitudes that must be possessed in order to fulfill the teaching profession effectively and efficiently". No explicit or implicit message about teaching critical thinking and critical thinking discussed within the scope of the study was encountered. In the definition of the Field Knowledge subfield competence under the Professional Knowledge competency field, it is referred to the critical thinking skill by saying that "he has an advanced level of theoretical, methodological and factual knowledge that includes the questioning perspective in his field". B2.6 of the Learning Environment Creation sub-field competency under the Professional Skills competency area. "Creates learning environments that improve students' high-level cognitive skills" and the sub-field competency of Managing Teaching and Learning Process B3.7. Emphasis is placed on critical thinking with the expressions "It prepares activities for students to think analytically in lessons" in the indicator numbered.

In the 2017-2023 Strategy Document, which aims to be a "roadmap" in teacher training and improvement of their qualifications, 3 main objectives and targets related to these goals are determined. 1. Purpose is to Ensure Employment of Highly Qualified, Well-educated and Professional Individuals as Teachers, 2. Purpose is to Make Teachers' Personal and Professional Development Continuous, and 3. Purpose is to Improve Perception of the Teaching Profession and Strengthen the Status of the Profession, and explanations regarding the objectives are made. In the context of teacher qualification, attention was paid to increasing pre-service practice and the establishment of a system for determining the most qualified candidates among the candidates who completed the training was mentioned. However, in the 32-page text, there was no explicit or implicit message about critical thinking and teaching critical thinking. Critical thinking is included only among the general expressions in the "presentation" and "introduction" parts of the text.

Discussion: In this study, The content of teacher training undergraduate programs (YÖK, 2018), teacher competencies (MEB, 2018) and teacher strategy document 2017-2023 (MEB, 2018) are discussed in terms of whether they contain expressions and explanations regarding the teaching of critical thinking and critical thinking. According to the research findings, these documents generally include education policies. In terms of teacher competencies and qualifications, the focus is on teacher employment. It is suggested that quality in education can be achieved by determining the best qualifications among the candidates or by evaluating the performance of existing teachers (MEB, 2018). Of course, these documents are expected to contain information and explanations about the status, personal rights and other expectations of the teaching profession. However, it is known that the needs in the teaching profession, which has multidimensionality and its affective aspects are inevitable, do not consist of these. These documents should contain guiding content for teacher candidates and teachers in order not to feel inadequate or underdeveloped in the face of the changing and transforming education paradigm. In addition, it is thought that more concrete statements about the quality of the teacher are needed in these informative documents, which are followed with interest and curiosity by all stakeholders such as teachers, teacher candidates, education administrators and academicians.

Conclusion and Suggestions: In the light of the findings, the following suggestions have been made:

- Institutions that strive for pre service and in-service development in teacher training, can use clear and detailed expressions that are far from political language, considering all the stakeholders of the education system in the document contents they publish.

- Considering the importance of gaining critical thinking skills to individuals, the Critical and Analytical Thinking course, which is among the vocational knowledge elective courses in teacher training programs, can be brought into "compulsory" status. 